\title{
STUDIES ON MYCOBACTERIUM AVIUM SUBSPECIES PARATUBERCULOSIS ISOLATED FROM SOME EGYPTIAN DAIRY FARMS
}

\author{
ABDEL MOGHNEY, A.F.; NASHWA, M. HELMY and ARAFA, A.A. \\ Animal Health Research Institute, Dokki, Giza, Egypt, 12618.
}

Email: abdelrasheedghanem@yahoo.com

Assiut University web-site: www.aun.edu.eg

\section{ABSTRACT}

Received at: 17/6/2015

The current study was carried out on three Egyptian dairy herds located at Alexandria, Ismailia and Mansoura, from 2009 to 2012. Those herds were suffering from clinical or subclinical infection of Mycobacterium avium subspecies paratuberculosis (MAP). The objective from this work is to identify circulating strains in some Egyptian dairy herds. Animals were tested for detection of anti Mycobacterium paratuberculosis antibodies by ELISA test. Animal fecal samples were cultured on Herrold's egg yolk medium (HEYM) supplemented with mycobactin-J. The confirmed positive results used for isolation of "MAP" from 11 out of 23 samples. Moreover, results of real time- PCR specific for IS900 gene of M. paratuberculosis on 23 fecal samples indicated the positivity of 21 fecal samples. Five bacterial isolates (two from Alexandria, two from Ismailia and one from Mansoura) were subjected to conventional PCR targeting a 413-bp fragment of the IS900. The 413 bp PCR purified product were subjected to sequencing. The obtained sequences were aligned and compared to other international strains of MAP using Basic Local Aligment Search Tool (BLAST). The sequencing data shows that 3 isolates were identical to each other (100\%) and to other strains from Europe (UK, Spain, Netherlands, Slovakia, Germany and Italy); the other 2 isolates show $98 \%$ similarity. Authors recommended that establishment of strict measures for mycobacterium avium subspecies paratuberculosis infections by the Egyptian authorities is very important.

Key words: Mycobacterium avium subsp.paratuberculosis, ELISA, HEYM, DNA, PCR, IS900, Sequence, Dairy farms, Egypt.

\section{INTRODUCTION}

Paratuberculosis or Johne's disease is a chronic debilitating disease that affects a wide range of animal hosts, both domestic and wild. Paratuberculosis has been recognized as a major problem in many livestock production systems (Lombard , 2011). It is a common disease in all countries with a significant dairy industry (Barrington et al., 2003). Paratuberculosis herd prevalence guesstimates in Europe, United States and south America appeared to be $50 \%, 21.6 \%$ and $70 \%$ respectively (Wells and Wagner 2000, Ferrerira et al., 2001, Alfaro et al., 2006, Nielsen and Toft 2009. Paratuberculosis is present in many species and regions in Egypt (Salem et al., 2005, Abdel Mogney 2008, Abdel Moghney et al., 2012 and Amin et al., 2015); While in neighbouring countries, studies indicated that the disease is established in some areas of Sudan (Ibrahim et al., 2004, Aradaib et al., 2005), and Libya, (Mustafa and Mugadmi 1986, Ali and Abdel Salam 1997), in Tunisian cattle (Gallo et al., 1989).

The complement fixation test and enzyme-linked immunosorbant assay identify antibodes against mycobacterium avium subspecies paratuberculosis while the microscopic examination of Ziehl-Neelsen stained faecal smears, faecal culture, and polymerase chain reaction (PCR) assays are methods to demonstrate the presence of mycobacterium avium subspecies paratuberculosis (Kalis et al., 2002). PCR and sequencing the amplified product are useful tools to predict the origin of a paratuberculosis infection, (Sohal et al., 2010).

The purpose of this study is to diagnose "MAP" infection within some Egyptian dairy farms using traditional diagnostic methods like serology and isolation and molecular methods like real time PCR as confirmatory test, in addition sequencing of PCR products targeting fragment of the IS900 gene as advanced techniques for tracing infection's source.

\section{MATERIALS and METHODS}

This study was carried out during 2009 - 2012, samples" $n=1118$ " were collected from three dairy herds(268 from Alexandria, 350 from Ismailia and 500 from Mansoura) previously tested for detection of anti Mycobacterium paratuberculosis antibodies in 
bovine serum by ELISA test with a main goal of using confirmed and advanced methods to diagnose and trace MAP within herds.

Blood and fecal samples (23 of each) were colleccted from ELISA positive (for paratuberculosis) animals representing 3 Egyptian governorates(Alexandria $n=$ 15, Ismailia $n=4$, and Mansoura $n=4$ )

- Serum antibody testing: ELISA Paratuberculosis antibody verification kit "Institute Pourquier" which approved by OIE (2004) was used procedure and results interpretation according to kit instructions.

- Bacterial culture: Fecal samples from seropositive animals for paratuberculosis were cultured onto (HEYM), supplemented with Mycobactin J for up to 4 months.

- Ziehl-Neelsen stain for isolated bacteria to demonstrate the acid fast bacilli using carbol fuchsin, hydrochloric alchol and methylene blue. Culture and Ziehl-Neelsen staining were done according to OIE terrestrial manual (2004).

- Molecular diagnosis: 23 fecal samples and 11 of isolated bacteria were tested using real time PCR, while 5 isolates were tested using conventional PCR with gel electrophoresis and sequencing of PCR products of the IS900 gene.

Extraction of DNA from faecal samples was performed according to instructions of QIAamp DNA Mini Kit. Extraction of DNA from mycobacterium paratuberculosis isolates was performed according to Sevilla et al. (2005).

Extracted DNA from fecal samples and bacteria were amplified with ADIAVET® PARATB REALTIME PCR Kit which uses primers and a TaqMan probe labeled with FAM, specific of M. paratuberculosis (IS900) for Real time PCR. Amplification of the IS900-based PCR was conducted in $25 \mu \mathrm{L}$ and under the following conditions: 1 initial cycle of denaturation and activation at $50{ }^{\circ} \mathrm{C}$ for 2 minutes, another cycle of denaturation at $95^{\circ} \mathrm{C}$ for 10 minutes and 45 cycles of denaturation at $95^{\circ} \mathrm{C}$ for $30 \mathrm{sec}$., annealing, extension and quantification at $60^{\circ} \mathrm{C}$ for 1 minute on thermocycler apparatus "Stratagene, USA".

Conventional PCR was conducted on five bacterial DNA extracts (two from Alexandria, two from Ismaelia and one from Mansoura) using two oligonucleotide primers P90B and P91B (Table 1). These primers constructed to target a 413-bp fragment of the IS900 of MAP (Singh et al., 2010).

Table 1: Oligonucleotide sequences of primers specific for MAP.

\begin{tabular}{ccc}
\hline Primers & Sequences & Amplified product \\
\hline P90B & 5-GAA GGG TGT TCG GGGCCGTCG CTT AGG -3 & \\
P91t'B & 5-GGC GTT GAG GTC GATCGC CCA CGT GAC -3 & 413-bp \\
\hline
\end{tabular}

Gel electrophoresis and sequencing: PCR products of $5 \mu \mathrm{l}$ were analyzed by electrophoresis on a $1.5 \%$ agarose gel containing ethidium bromide with final concentration of $0.5 \mu \mathrm{g} / \mathrm{ml}$ at $95 \mathrm{~V}$ for $30 \mathrm{~min}$ in $1 \mathrm{x}$ Tris Borate EDTA (TBE) buffer, against GeneRuler $^{\mathrm{TM}} 100$ bp Plus DNA Ladder (Fermentas). Images of the gels were taken on BioDoc Analyze Digital Systems (Biometra, Germany). Gel containing DNA band of the expected size (413bp) was excised and purified with the QIAquick Gel Extraction Kit (Qiagen) according to the manufacturer's instruction.

Five purified PCR products were sequenced directly at Gene analysis unit, NL_QP, Animal Health Research Institute, Egypt using the ABI-PRISM® BigDyeTM Terminators v3.1 Cycle Sequencing Kit (Applied Biosystems, Foster City, CA, USA) and the ABI PRISM® 3130 genetic analyzer (Applied Biosystems). The sequences were edited with SeqScape ${ }^{\circledR} \quad$ Software Version 2.5(Applied Biosystems). Bacterial sequences in this study were aligned and compared to international M. avium subspecies sequences in genebank using BLAST software, while, the assembly of the consensus sequences, alignment trimming and phylogenetic tree were performed with the Lasergene DNASTAR group of programs (DNASTAR Inc., Madison,WI).

The sequences of IS900 gene of the 5 Egyptian isolates were submitted to Genbank under accession numbers: KJ173780 to KJ173784.

\section{RESULTS}

Phenotypic characteristics: The grown colonies after 4 months incubation, the inoculated HEYM slants, the isolates revealed acid fast bacilli after staining with Ziehl-Neelsen (Fig 1, 2, 3 and Tables 2, 3). The inoculated slants revealed the isolated strains on "HEYM" with mycobactin J, growth were observed after 4 weeks as small pin point colonies without pigmentation and at the end of observation period (16 weeks), the colonies kept their appearance with larger size and more in number (Fig.1), in addition HEYM still green except one sample from mansoura and another sample from Ismaelia, the colonies were creamy, and the media changed to faint green color (Fig.2). Pin point colonies were grown on HEYM. All isolates revealed acid fast bacilli after staining with Ziehl-Neelsen (Fig.3). 


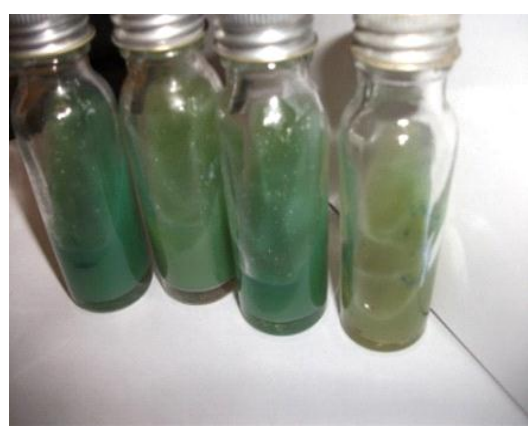

Fig.(1) colonies grown on HEYM with mycobactin $\mathrm{J}$

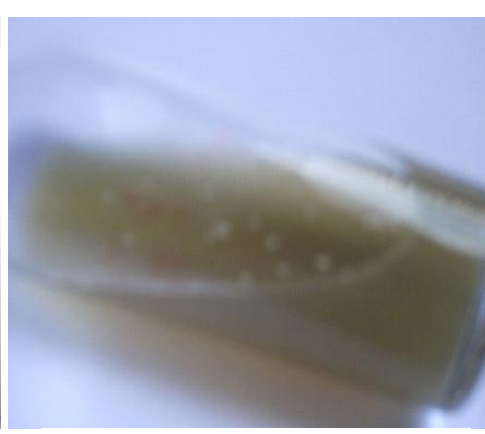

Fig.(2) Creamy colonies with faint green colored media

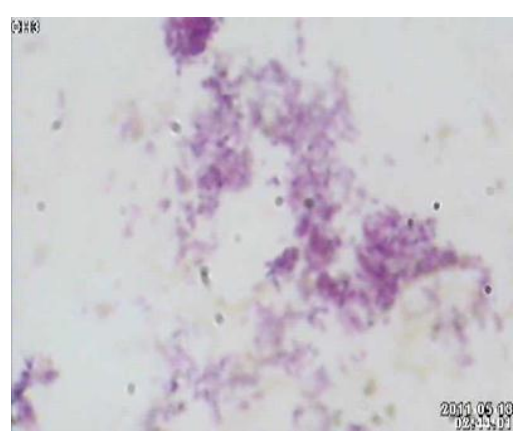

Fig.(3) Clumps of Acid fast bacilli after staining with ZiehlNeelsen.

Table 2: Results of ELISA, Fecal culture, and Fecal PCR of 23 cattle from (Alexandria, Ismaelia and Mansoura) herds.

\begin{tabular}{cccc}
\hline Herd & $\begin{array}{c}\text { (ELISA, Fecal Culture, } \\
\text { Fecal PCR) +ve }\end{array}$ & $\begin{array}{c}\text { (ELISA, Fecal PCR) +ve } \\
\text { (Fecal Culture) -ve }\end{array}$ & $\begin{array}{c}\text { (Fecal Culture, Fecal PCR)-ve } \\
\text { (ELISA) +ve }\end{array}$ \\
\hline $\begin{array}{c}\text { Alexandria } \\
\mathrm{n}=15\end{array}$ & 6 & 7 & 2 \\
\hline Ismaelia $\mathrm{n}=4$ & 3 & 1 & ----- \\
\hline Mansoura $\mathrm{n}=4$ & 3 & 1 & ----- \\
\hline Total $(23)$ & 12 & 9 & 2 \\
\hline
\end{tabular}

Table 3: Comparison between results of fecal culture and culture PCR.

\begin{tabular}{|c|c|c|c|}
\hline Herd & sample no. & Fecal culture on HEYM & Culture real-time PCR CT.* \\
\hline \multirow{6}{*}{$\begin{array}{c}\text { Alexandria } \\
n=6\end{array}$} & 5639 & $+\mathrm{Ve}$ & $--\mathrm{Ve}$ \\
\hline & 5398 & $+\mathrm{Ve}$ & 21.33 \\
\hline & 863 & $+\mathrm{Ve}$ & --ve \\
\hline & 4 & $+\mathrm{Ve}$ & 38.76 \\
\hline & 27 & $+\mathrm{Ve}$ & 17.72 \\
\hline & 5592 & $+\mathrm{Ve}$ & 30.45 \\
\hline \multirow[t]{3}{*}{ Ismaelia $n=4$} & 631 & $+\mathrm{Ve}$ & 22.8 \\
\hline & 21 & $+\mathrm{Ve}$ & 18.74 \\
\hline & 3 & $+\mathrm{Ve}$ & 22.33 \\
\hline \multirow[t]{3}{*}{ Mansoura $n=4$} & 8 & $+\mathrm{Ve}$ & 20.87 \\
\hline & 5 & $+\mathrm{Ve}$ & 19 \\
\hline & 2 & $+\mathrm{Ve}$ & 32.33 \\
\hline
\end{tabular}

$* * \mathrm{CT}=$ Cut threshold (interpretation values: positive $\rightarrow \leq 40$ Negative $>42$ )

Table 4: percentage of results for paratuberculosis diagnostic tests.

\begin{tabular}{cccc}
\hline Herd location & ELISA $(\mathrm{p} / \mathrm{t})$ & Faecal culture $(\mathrm{p} / \mathrm{t})$ & Fecal PCR $(\mathrm{p} / \mathrm{t})$ \\
\hline Alexandria & $100 \%(15 / 15)$ & $40 \%(6 / 15)$ & $86.66 \%(13 / 15)$ \\
\hline Ismaelia & $100 \%(4 / 4)$ & $75 \%(3 / 4)$ & $100 \%(4 / 4$ \\
\hline Mansoura & $100 \%(4 / 4)$ & $75 \%(3 / 4)$ & $100 \%(4 / 4)$ \\
\hline Total & $100 \%(23 / 23)$ & $52.17 \% \quad((12 / 23)$ & $91.30 \%(21 / 23)$ \\
\hline
\end{tabular}

$\mathrm{p} / \mathrm{t}=$ positive/total 


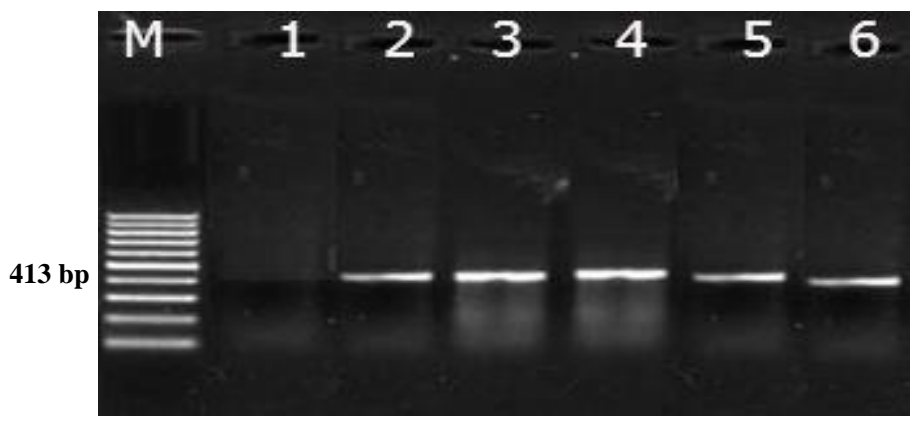

Fig. (4):Agarose gel electrophoresis of PCR-amplified IS900 gene fragments from MAP strains. The figure shows a single band 413-bp DNA fragment. M: 100 bp DNA marker (Fermentas). Lane 1: negative control. .Lanes 2-6: MAP strains isolated from Ismaelia farm "2 strains", Mansoura farm"one strain" and Alexandria farm"2 strains".

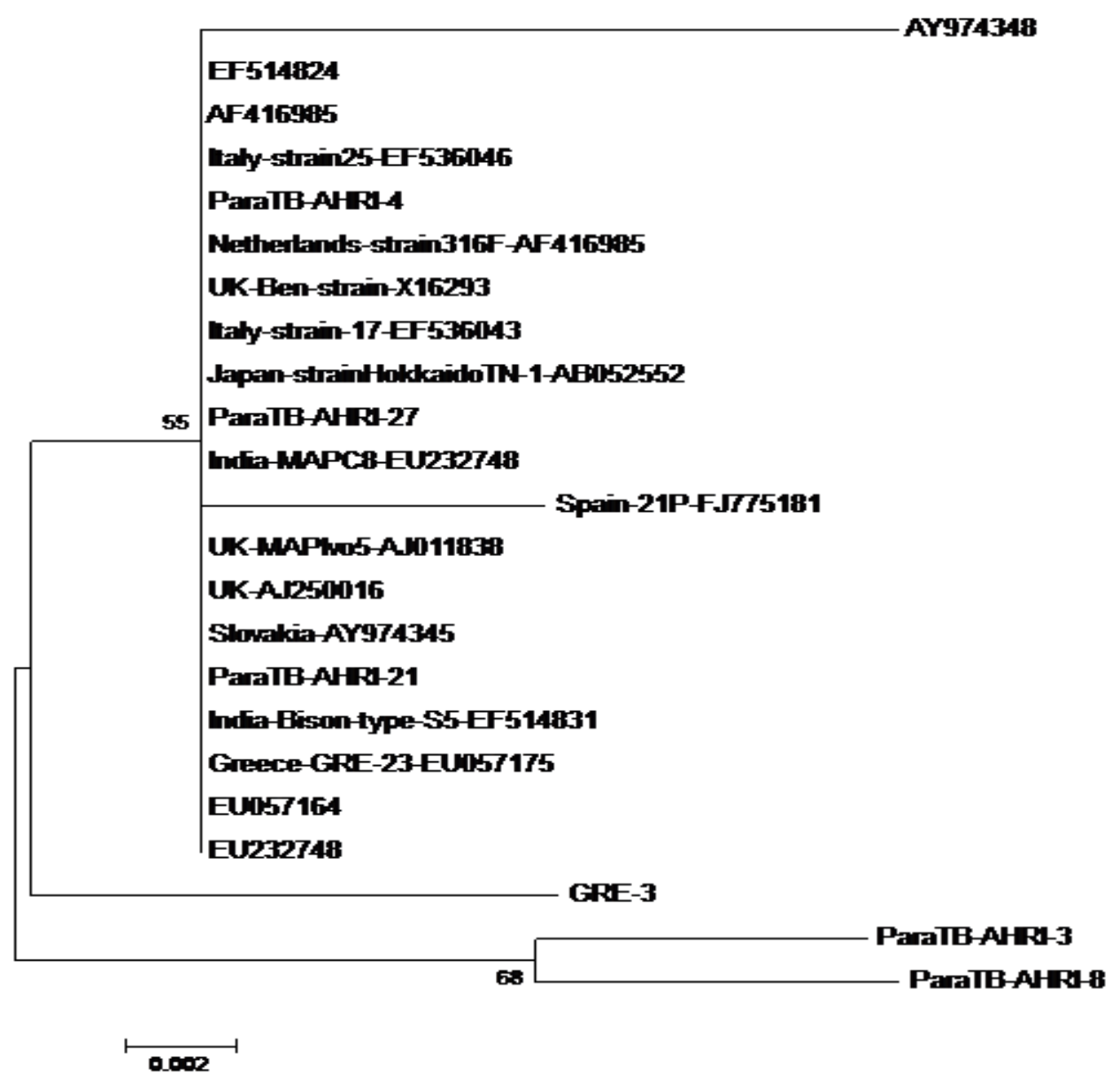

Figure (5): Phylogenetic analysis of Mycobacterium. avium subsp. Paratuberculosis of Egyptian strains in comparison to other international strains

Based on these results (Fig.1, 2. 3 and Tables 2, 3), 5 isolates selected were for sequencing of IS900 gene. Three of them shared in their phenotypic characteristics, sample no.4 "Alexandria, which was imported from Germany; sample no.27"Alexandria, from the same farm; sample no. 21 "Ismaelia". The other two samples no.3 "Ismaelia" and no.8 "Mansoura " which had creamy colonies and green yellow colored media, Fig.(2) that supports to be belonging to mycobacterium paratubeculosis type "S" strain. The selection of the 5 isolates for sequencing aimed to genotyping and strain identification and to predict the origin or the source of infection. 
Table 5: Sequences comparison of IS900 gene of Egyptian isolated Mycobacterium avium subsp. Paratuberculosis

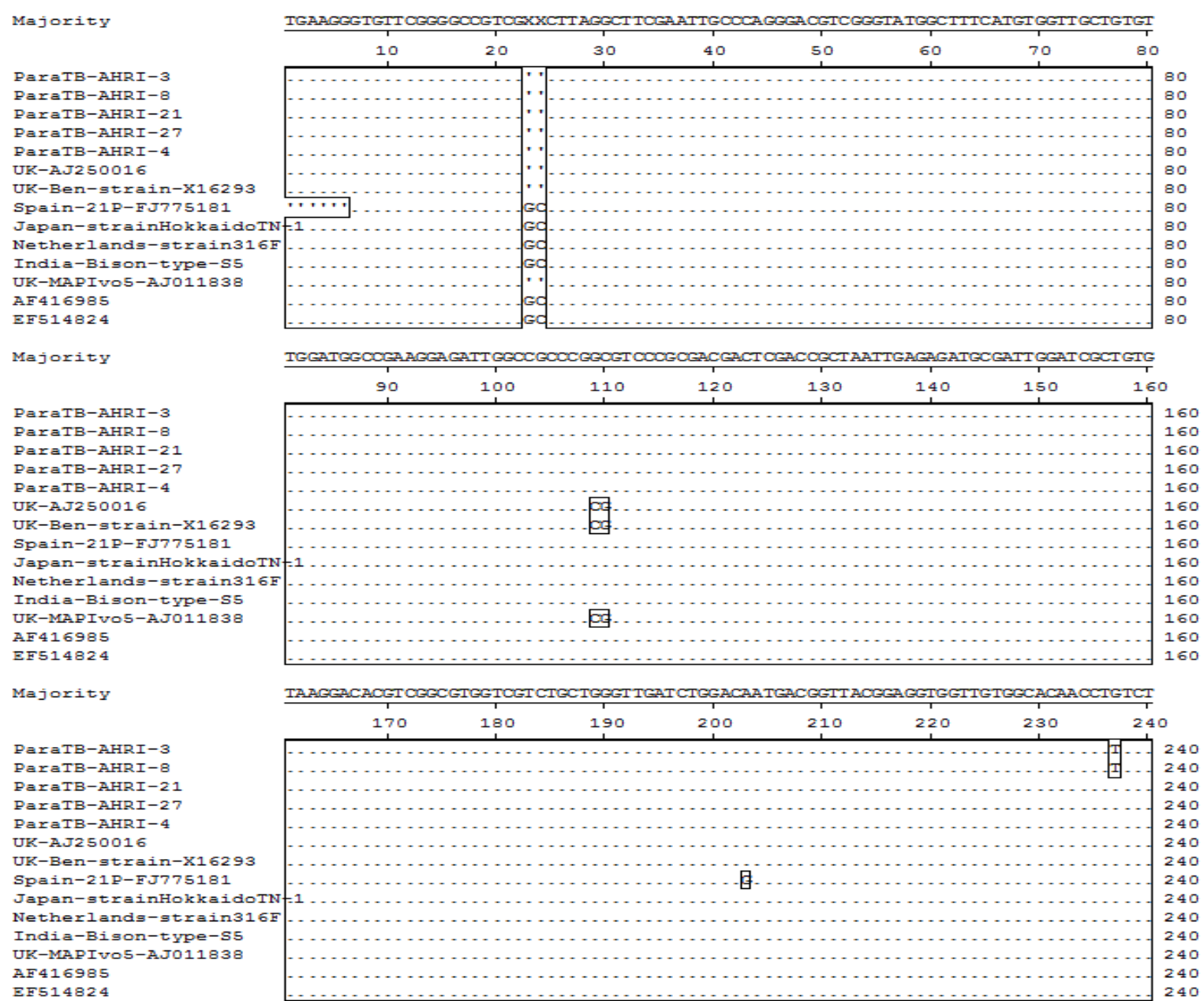

AF 416985

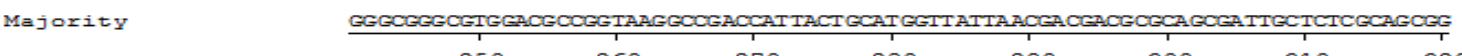

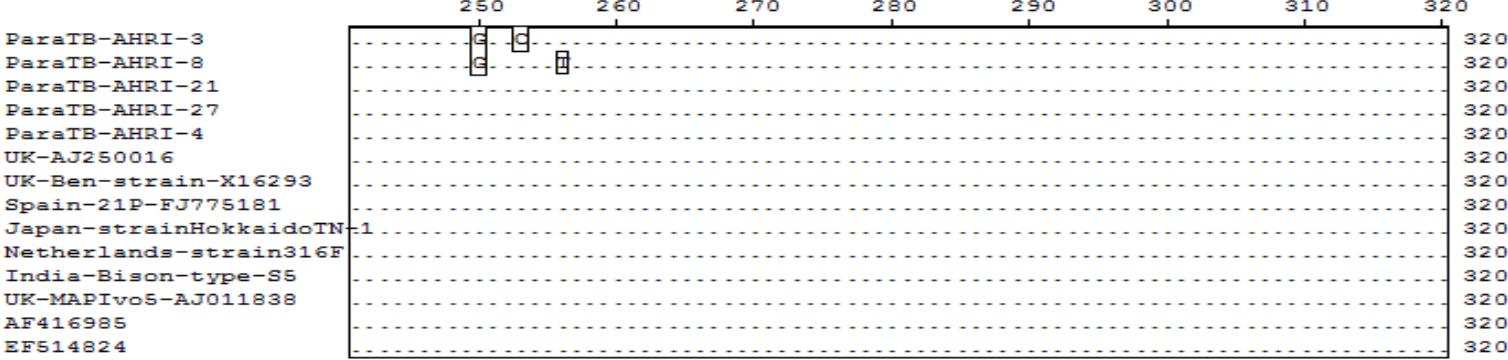

Majority GIGGCCAACEACEAGGCCGCGCTGCTEGAGTI EATIGCGGCE

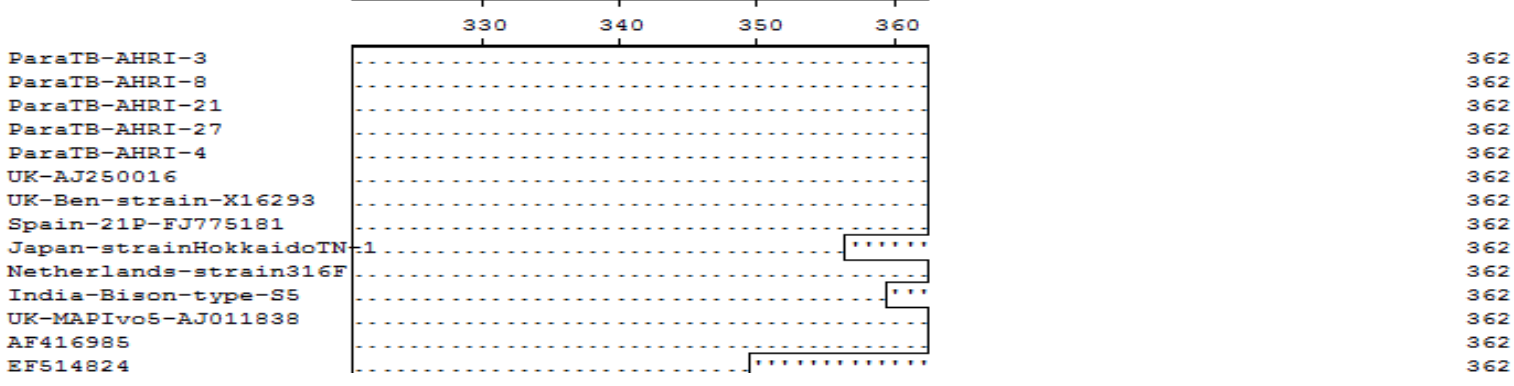

PCR results (table 2, 3 and Fig 4) confirmed that extracted DNA from fecal and bacteria were mycobacterium avium subspp. Paratuberculosis. 
Table 6: percent identity of IS900 gene of Egyptian isolated Mycobacterium avium subsp. Paratuberculosis with some worldwide strains.

\begin{tabular}{|c|c|c|c|c|c|c|c|c|c|c|c|c|c|c|c|c|}
\hline \multicolumn{17}{|c|}{ Percent Identity } \\
\hline & 1 & 2 & 3 & 4 & 5 & 6 & 7 & 8 & 9 & 10 & 11 & 12 & 13 & 14 & & \multirow[b]{2}{*}{ ParaTB-AHRI-3 } \\
\hline 1 & & 98.9 & 98.6 & 98.6 & 98.6 & 98.1 & 98.1 & 96.7 & 97.0 & 98.6 & 97.8 & 98.1 & 98.6 & 95.0 & 1 & \\
\hline 2 & 0.6 & & 98.6 & 98.6 & 98.6 & 98.1 & 98.1 & 96.7 & 97.0 & 98.6 & 97.8 & 98.1 & 98.6 & 95.0 & 2 & ParaTB-AHRI-8 \\
\hline 3 & 0.8 & 0.8 & & 99.4 & 99.4 & 98.9 & 98.9 & 97.5 & 97.8 & 99.4 & 98.6 & 98.9 & 99.4 & 95.9 & 3 & ParaTB-AHRI-21 \\
\hline 4 & 0.8 & 0.8 & 0.0 & & 99.4 & 98.9 & 98.9 & 97.5 & 97.8 & 99.4 & 98.6 & 98.9 & 99.4 & 95.9 & 4 & ParaTB-AHRI-27 \\
\hline 5 & 0.8 & 0.8 & 0.0 & 0.0 & & 98.9 & 98.9 & 97.5 & 97.8 & 99.4 & 98.6 & 98.9 & 99.4 & 95.9 & 5 & ParaTB-AHRI-4 \\
\hline 6 & 1.4 & 1.4 & 0.6 & 0.6 & 0.6 & & 99.4 & 97.0 & 97.2 & 98.9 & 98.1 & 99.4 & 98.9 & 95.3 & 6 & UK-AJ250016 \\
\hline 7 & 1.4 & 1.4 & 0.6 & 0.6 & 0.6 & 0.0 & & 97.0 & 97.2 & 98.9 & 98.1 & 99.4 & 98.9 & 95.3 & 7 & UK-Ben-strain-X16293 \\
\hline 8 & 1.1 & 1.1 & 0.3 & 0.3 & 0.3 & 0.9 & 0.9 & & 96.4 & 98.1 & 97.2 & 97.0 & 98.1 & 94.5 & 8 & Spain-21P-FJ775181 \\
\hline 9 & 0.9 & 0.9 & 0.0 & 0.0 & 0.0 & 0.6 & 0.6 & 0.3 & & 98.3 & 98.3 & 97.2 & 98.3 & 96.4 & 9 & Japan-strainHokkaidoTN-1 \\
\hline 10 & 0.8 & 0.8 & 0.0 & 0.0 & 0.0 & 0.6 & 0.6 & 0.3 & 0.0 & & 99.2 & 98.9 & 100.0 & 96.4 & 10 & Netherlands-strain $316 \mathrm{~F}$ \\
\hline 11 & 0.8 & 0.8 & 0.0 & 0.0 & 0.0 & 0.6 & 0.6 & 0.3 & 0.0 & 0.0 & & 98.1 & 99.2 & 96.4 & 11 & India-Bison-type-S5 \\
\hline 12 & 1.4 & 1.4 & 0.6 & 0.6 & 0.6 & 0.0 & 0.0 & 0.9 & 0.6 & 0.6 & 0.6 & & 98.9 & 95.3 & 12 & UK-MAPIV05-AJ011838 \\
\hline 13 & 0.8 & 0.8 & 0.0 & 0.0 & 0.0 & 0.6 & 0.6 & 0.3 & 0.0 & 0.0 & 0.0 & 0.6 & & 96.4 & 13 & AF416985 \\
\hline \multirow[t]{2}{*}{14} & 0.9 & 0.9 & 0.0 & 0.0 & 0.0 & 0.6 & 0.6 & 0.3 & 0.0 & 0.0 & 0.0 & 0.6 & 0.0 & & 14 & \multirow[t]{2}{*}{ EF514824 } \\
\hline & 1 & 2 & 3 & 4 & 5 & 6 & 7 & 8 & 9 & 10 & 11 & 12 & 13 & 14 & & \\
\hline
\end{tabular}

Sequencing data of 413 bp amplified product of IS900 gene:

Samples AHRI-3 (Ismaelia) and AHRI-8 (Mansura) showing $98 \%$ similarity resulting from a single nucleotide polymorphism (SNP) at position 237, with a $\mathrm{T}$ instead of an $\mathrm{G}$, in comparison to other sequences from Egypt or worldwide. Samples AHRI4 (Alexandria, imported from Germany), sample AHRI-21 (Ismaelia) and AHRI-27 (Alexandria) showed $100 \%$ identity with each other and high similarity to other strains from Europe (Fig. 5) (strains from UK, Spain, Netherlands, Slovakia, Germany and Italy) without any sequence modifications.

Three isolates, Isamelia (one sample) and Alexandria (two samples) showed $100 \%$ identity. While the results indicated that isolates of Ismaelia herd were unidentical (samples AHRI-3, AHRI-21).

\section{DISCUSSION}

In the present study, clinical stage of paratuberculosis was the predominant sign, ELISA results showed high titre (SP\%= 142.9-295) of immunoglobuline G1 antibodies for MAP (table 2), which coincide with (Stabel 2000, Coussens 2001). The late stage of subclinical phase of mycobacterium avium subspecies paratuberculosis was characterized by production of immunoglobulin G1 antibodies, predominates, this shift in the predominant immune response is often associated with progression to clinical disease. The fecal culture of animals with highest ELISA S/P showed more colonies per culture tube which indicate that cows are heavy fecal shedders with high risk factors on environment and susceptible cows (Fecteau and Whitlock 2010). While the negative cultured samples 11/23 (Table 3) may be due to that shedding of microorganisms was below the limit of detection at the time of sampling. These results support the need for caution when interpreting negative results from a single fecal culture (Barrington et al., 2003).

Direct amplification of fecal MAP DNA by real time PCR (table 2), revealed $91.30 \%$ agreement (table 4) with ELISA where there were two samples negative which may be attributed to presence of inhibitory substances in fecal matter or due to intermittently shedding of MAP in feces with differing concentrations (Coussens, 2001 and David and Göran 2006).

Although, animals of Ismaelia \& Mansoura farms (table 2) were clinically infected, fecal samples of 2 cases showed negative results by culture method on HEYM with mycobactin $\mathrm{J}$ while by real time PCR showed positive results. So, additional of other culture media like BACTEC may be useful in future further study. The results agree with Pierre et al. (2010) who mentioned that high-throughput PCR tests have the potential to provide rapid (less than 2 days) detection of M. avium subsp. Paratuberculosis at a cost comparable to or less than that of conventional culture (16-20 weeks).

Sixty percent of Alexandria fecal culture (9/15) were negative. Poor sensitivity may be due to small numbers of bacilli in subclinical stage of disease or the treatment of samples with hexadocylepyridenium chloride (HPC) for decontamination before culture. MAP, though culture is a sensitive because live undamaged bacilli are necessary for culture but only qualitatively preserved DNA are required for PCR (Altwegg 1995). Moreover the difference between positive fecal culture $(\mathrm{n}=12)$ with acid fast bacilli on staining with ziehl-neelsen (Table 3$)$ and culture PCR $(n=10)$ was unclear since the two cases showed weak positive 
with Fecal PCR . Overall fecal samples for PCR revealed $91.3 \%(21 / 23)$ positive, otherwise 2 negative samples were in complete agreement with results of culture results.

In the present study the isolated strains were phenotypically (growth on HEYM and mycobactin dependent) and genotypically (by the presence of multiple copies of an insertion element IS900) classified as mycobacterium avium subspecies paratuberculosis (Collins and de Lisle 1986, Thorel et al., 1990).

The five selected MAP isolates from 3 separate geographical locations which confirmed by amplification of $413 \mathrm{bp}$ of IS900 gene specific for bacteria using conventional PCR. Three isolates, Isamelia (one sample) and Alexandria (two samples) shows $100 \%$ identity (table 5) which reflects the same origin of animals in the farms from those governorates. However Ismaelia farm has 2 unidentical isolates (samples 3, 21) that reflect importation of animals from different sources or introducing new animals from other farms. These results indicate presence of 2 different strains from Mycobacterium avium subsp. paratuberculosis circulating in those three herds according to the current study (Fig.4 ). Unique (SNPs) were recently reviewed and DNA sequencing for the detection of polymorphism has been considered to be promising for the differentiation of MAP strains (Castellanos et al., 2009). Source tracking is one of the most common applications for molecular epidemiological methods (Zadoks and Schukken 2006). Strain typing can elucidate from where the infectious agent originated and may help to understand ways and risk factors for transmission, therefore sample AHRI-4 "Alexandria" has a special attention as it was imported from Germany and transferred to the farm after quarantine period. DNA sequencing of Sample AHRI-4 showed 100\% identity with European strains (fig.4), which was in complete agreement with Fernandez-Silva et al. (2012). Mycobacterium avium subspecies paratuberculosis isolated from symptomatic dairy cattle in Germany is similar to those previously determined in other parts of Europe. Based on these data, the main possibility for disease occurrence is the transmission of new infected animals either by importation or purchasing from infected source otherwise the mechanical transmission.

\section{RECOMMENDATION}

Establishment of strict control measures for mycobacterium avium subspecies paratuberculosis infections by the Egyptian authorities is very important.

\section{REFERENCES}

Abdel Moghney, A.F. (2008): Prevalence of paratuberculosis within some dairy farms in different egyptian governorates. 13th Sci. Cong. 2008, Fac. Vet. Med., Assiut Univ., Egypt 604-628.

Abdel Moghney, A.F.; Nashwa, M. Helmy; Fayza, A.Al Tedawy and Amany A. Sallam, (2012): Bacteriological, Molecular and Biochemical studies on cattle infected with paratuberculosis. Egypt. J. Agric. Res., 90(1), 153-169.

Alfaro, C.; de Rolo, M.; Clavijo, A. and Valle, A. (2006): Characterization of bovine paratuberculosis in dual purpose cattle at the plains of Monagas state, Venzuela. Zootecina Tropical 24, 321-332.

Ali, O.A. and Abdel Salam, E.B. (1997): Incidence of animal diseases in Tripoli (Libya): a ten-year (1982-1991) pathological survey. Sudan Journal of Veterinary Science and Animal Husbandry 36, 141-148.

Altwegg, M. (1995): General problrms associated with diagnostic applications of amplification methods. J. Microbiol Methods 23, 21-30.

Amin S. Adel; Chung-Yi Hsu; Samah F. Darwish; Pallab Ghosh; Eman M. AbdEl-Fatah; Tahani S. Behour and Adel M. Talaat (2015): Ecology and genomic features of infection with Mycobacterium avium subsecies paratuberculosis in Egypt. Microbiology, Vol. 161, 807-818.

Aradaib, IE.; Abbas, ZA. and El-Sanousi, SM. (2005): Evaluation of conventional methods and nested PCR(nPCR) for detection of paratuberculosis in goats. Veterinary Research Communications 29, 381-385.

Barrington, G.M.; John, M.G.; Inge, S.E.; William, C.; Davis, J.F.; Evermann, C.E. and Jennifer, L. (2003): Temporal patterns of diagnostic results in serial samples from cattle with advanced Paratuberculosis. Infections $\mathrm{j}$ Vet. Diagn Invest. 15, 195-200.

Castellanos, E.; Aranaz, A.; deJuan, L.; Alvarez, J. and Rodriguez, S. (2009): Single nucleotide polymorphisms in the IS900 sequence of Mycobacterium avium subsp. paratuberculosis are strain type specific. J. Clin Microbiol 47, 2260-2264.

Collins, D.M. and de Lisle, G.W. (1986): Restriction endonuclease analysis of various strains of Mycobacterium paratuberculosis isolated from cattle. Am J. Vet. Res. 47, 2226-2229.

Coussens, P.M. (2001): Interactions between Mycobacterium paratuberculosis and the bovine immune system. Anim. Health Res. Rev. 2, 141-161.

David, H. and Göran, B. (2006): New PCR systems to confirm real-time PCR detection of 
Mycobacterium avium subsp.

Paratuberculosis. BMC Microbiology, 76-87.

Fecteau, M.E. and Whitlock, R.H. (2010): Paratuberculosis in cattle. In: Behr, M.A., Collins, D.M. (Eds.), paratuberculosis: Organism,Disease, Control.CAB International, Oxfordshire, 144-156.

Fernandez-Silva, J.A.; Abdulmawjood, A.; Akineden, O.; Drager, K. and Klawonn, W.; Bulte, M. (2012): Molecular epidemiology of Mycobacterium avium subsp. Paratuberculosis at a regional scale in Germany. Research in Veterinary Science 93, 776-782.

Ferrerira, R.; Fonseca, L.S. and Lilenbaum, W. (2001): Detection of anti-Mycobacterium paratuberculosis antibodies in herds from Rio de Janerio, Brazil. Brazilian journal of Veterinary Medicine 23, 166-171.

Gallo, C.; Vesco, G.; Campo, F.; Haddad, N. and Abdelmoula, H. (1989): Disease survey among goats and dromedaries in southern Tunisia. Maghreb veterinaire 4, 15-17.

Ibrahim, A.; El-Sanousi, S. and Aradaib, I. (2004): Detection of Mycobacterium avium subspecies paratuberculosis using nested polymerase chain reaction (nPCR). Veterinarski Arhiv 74, 27-35.

Kalis, C.H.; Barkema, H.W.; Hesselink, J.W.; Van, C. and Collins, M.T. (2002): Evaluation of two absorbed enzyme-linked immunosorbent assays and a complement fixation test as replacements for fecal culture in the detection of cows shedding Mycobacterium avium subspecies paratuberculosis. J. Vet. Diagn Invest.14, 219-24.

Lombard, JE. (2011): Epidemiology and economics of paratuberculosis.Vet. Clin. Food Anim. 27, 525-535.

Mustafa, A.A. and Mugadmi, K.E. (1986): First report of paratuberculosis (John's disease) in Libya. Veterinary Record 118: 26, 729.

Nielsen, S.S. and Toft, N. (2009): A review of prevalence of paratuberculosis in farmed animals in Europe. Prev. Vet. Med. 88, 1-14.

Oie (2004): Manual of diagnostic tests and vaccines for terrestrial Animals (mammals, birds and bees). 5th edition. Paratuberculosis (Johne's disease), chapter 22.6.

Oie (2009): Detailed disease incidence: paratuberculosis.

Pierre, E.D.; William, C.; Jim, B.; Aidan, C. and Jim, M.O. (2010): Isolation and detection of Mycobacterium avium subsp. paratuberculosis (MAP) from cattle in Ireland using both traditional culture and molecular based methods Gut Pathog. 2, 11
Salem, M.; Zeid, A.A.; Hassan, D. and EL-Sayed, A. (2005): Zscoeck, M. Studies on johne's disease in Egyptian cattle. J. Vet. Med. 52, 134-137.

Sevilla, I. Singh, S.V.; Garrido, J.M.; Aduriz, G.; Rodríguez, S. and Geijo, M.V. (2005): Molecular typing of Mycobacterium avium subspecies paratuberculosis strains from different hosts and regions. Rev. sci. tech. Off. int. Epiz. 24, 1061-1066.

Shoal, J.S.; Singh, S.V.; Singh, A.V. and Singh, P.K. (2010): Strain diversity within Mycobacterium avium subspecies paratuberculosis-a review. Indian Journal of experimental biology. 48, 7-16.

Singh, N.; Singh, S.V.; Gupta, V.K.; Sharma, V.D.; Sharma, R.K. and Katoch, V.M. (1996): Isolation and identification of mycobacterium paratuberculosis from naturally infected goatherds in india. Indian J. Vet. Path. 20, 104-108.

Singh, P.K.; Singh, S.V.; Kumar, H.; Shoal, J.S. and Singh, A.V. (2010): Diagnostic Application of IS900 PCR Using Blood as a Source Sample for the Detection of Mycobacterium avium Subspecies Paratuberculosis in Early and Subclinical Cases of CaprineParatuberculosis. Veterinary Medicine International, 1-8.

Stabel, J.R. (2000): Transitions in immune responses to Mycobacterium paratuberculosis. Vet. Microbiol. 77, 465-473.

Thorel, M.F.; Drichevsky, M. and Lévy-Frébault, V. (1990): Numerical taxonomy of mycobactindependent Mycobacteria, amended description of Mycobacterium avium, and description of Mycobacterium avium subsp. avium subsp. nov., Mycobacteriumavium subsp. paratubercu losis subsp. nov., and Mycobacterium avium subsp. silvaticum subsp. nov. Int J. Syst Bacteriol. 40, 254-260.

Wells, S.J. and Wagner, B.A. (2000): Herd-level risk factors for infection with mycobacterium paratuberculosis in US dairies and association between familiarity of the herd managerwith the disease or prior diagnosis of the disease in that herd and use of preventive measures. J. Am. Vet. Med. Assoc. 216, 1450-1457.

Whitlock, R.H. and Buergelt, C. (1996): Preclinical and clinical manifestation of paratuberculosis (including pathology). Vet. Clin. North Am. Food Anim Prac. 12, 345-356.1.

Zadoks, R.N. and Schukken, Y.H. (2006): Use of molecular epidemiology in veterinary practice. Vet. Clin. North Am. Food Anim. Pract. 22, 229-261. 


\section{دراسات عن المتفطرة الطيرية لسلالة نظير السل المعزولة من بعض مزارع الألبان المصرية \\ عبل الرشبي فتحى عبل المغتى ، نشوى محمد طلى ، عبل الستار عرفه \\ Email: abdelrasheedghanem@yahoo.com \\ Assiut University web-site: www.aun.edu.eg}

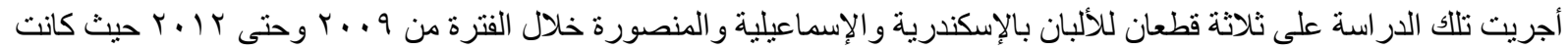

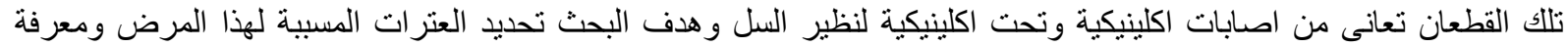

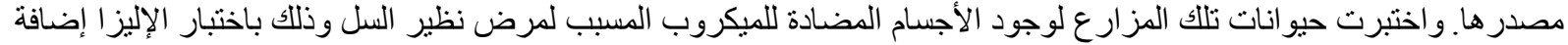

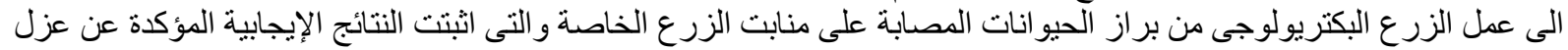

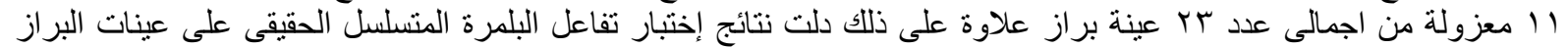

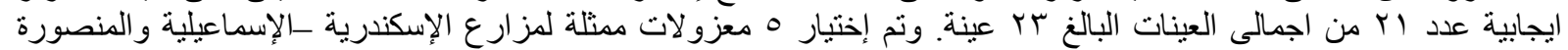

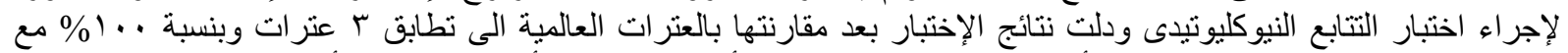

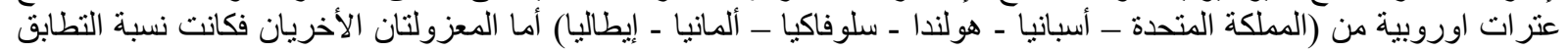

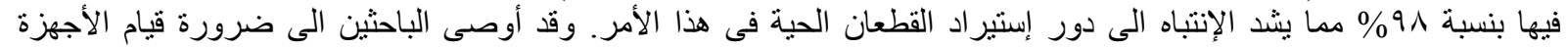

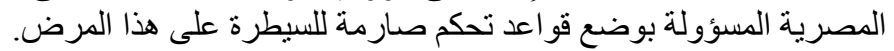

